\title{
KOMPATIBILITAS METARHIZIUM ANISOPLIAE DAN EKSTRAK DAUN BABADOTAN UNTUK MENGENDALIKAN HAMA KEPIK HIJAU DI LABORATORIUM
}

\author{
Siti Jarlina, Lestari Wibowo \& Agus M. Hariri \\ Jurusan Agroteknologi, Fakultas Pertanian Universitas Lampung, \\ Jl. Prof. SoemantriBrodjonegoro, No. 1, Bandar Lampung 35145 \\ E-mail:jarlina271092@gmail.com
}

\begin{abstract}
ABSTRAK
Pemanfaatan jamur entomopatogen dan pestisida nabati secara terpisah telah banyak dilakukan untuk pengendalian hama. Selanjutnya penggunaan secara bersama antara jamur entomopatogen dan pestisida nabati juga sedang dikembangkan. Penelitian ini bertujuan untuk mengetahui kompatibilitas jamur entomopatogen Metarhizium anisopliae dan ekstrak daun babadotan serta pengaruhnya terhadap mortalitas Nezara viridula. Pelaksanaan penelitian ini terdiri dari dua tahap, yaitu pertama uji kompatibilitas M. anisopliae dengan ekstrak daun babadotan pada media PDA, kedua adalah aplikasi campuran suspensi M. anisopliae dan ekstrak daun babadotan terhadap N. viridula. Hasil percobaan menunjukkan bahwa M. anisopliae tidak kompatibel dengan ekstrak daun babadotan. Hal tersebut ditunjukkan oleh penurunan pertumbuhan koloni, daya kecambah dan sporulasi jamur M. anisopliae. Selain hal itu diketahui bahwa Aplikasi suspensi M. ansiopliae dan aplikasi ekstrak daun babadotan secara tunggal menyebabkan mortalitas $N$. viridula yang tidak berbeda nyata antara keduanya. Aplikasi suspensi $M$. anisopliae dengan penambahan ekstrak daun babadotan $2 \mathrm{ml}$ dan $3 \mathrm{ml}$ menyebabkan mortalitas yang lebih tinggi dibandingkan mortalitas $N$. viridula pada aplikasi tanpa penambahan ekstrak babadotan.
\end{abstract}

Kata kunci: ekstrak daun babadotan, kompatibilitas, Metarhizium anisopliae, Nezara viridula

\section{PENDAHULUAN}

Nezara viridula L. (Hemiptera: Pentatomidae) atau kepik hijau merupakan hama yang banyak menyerang berbagai jenis tanaman di daerah tropis maupun subtropis (Kalshoven, 1981). Beberapa jenis tanaman yang menjadi inang hama tersebut antara lain kacang-kacangan, padi, jagung, tembakau, kentang, dan cabai. Tanaman pangan yang terserang hama ini dapat menjadi kerdil sehingga kuantitas maupun kualitas hasil panen serta daya kecambah akan menurun (Harahap dan Tjahjono, 2004).

Pengendalian hama pada tingkat petani umumnya menggunakan pestisida kimia sintetik. Pengunaan pestisida kimia sintetik yang berlebihan akan meninggalkan residu bagi lingkungan, mengganggu kesehatan manusia bahkan juga berpengaruh buruk terhadap organisme lain bukan target. Oleh karenanya dibutuhkan alternatif pengendalian lain misalnya penggunaan jamur entomopatogen seperti $M$. anisopliae (Sarjan, 2007).

M. anisopliae adalah salah satu jamur entomopatogen yang memiliki spektrum luas dan dapat menginfeksi hama lebih dari 100 spesies dari beberapa ordo serangga (Willis, 2010). Jamur ini dapat menyebabkan kelumpuhan otot serangga (Samuels, 1998).

Selain penggunaan jamur entomopatogen $M$. anisopliae, alternatif pengendalian yang lain adalah menggunakan pestisida nabati. Salah satu tumbuhan yang berpotensi sebagai pestisida nabati adalah babadotan (Ageratum conyzoides). Tumbuhan ini mengandung saponin, flavonoid, polifenol, dan minyak atsiri (Plantus, 2008 dalam Sianturi, 2009). Lebih lanjut Samsudin (2008) menyatakan bahwa kandungan aktif ekstrak babadotan mampu menghambat pertumbuhan larva $S$. litura menjadi pupa.

Saat ini mulai banyak dikembangkan pengkombinasian antara jamur entomopatogen dan pestisida nabati yang diharapkan aplikasinya akan lebih efektif. Menurut Prayogo (2011), kombinasi antara jamur L. lecanii dengan beberapa insektisida nabati seperti serbuk biji srikaya (Annona squamosa), serbuk biji jarak (Jatropha curcas), dan daun pacar cina (Aglaia odorata) bersifat sinergis. Sedangkan pengaruh jamur entomopatogen $M$. anisopliae terhadap suatu jenis hama jika digunakan secara bersama dengan ekstrak daun babadotan belum banyak dilaporkan. Penelitian ini bertujuan untuk mengetahui kompatibilitas jamur entomopatogen $M$. anisopliae dan ekstrak daun 
babadotan serta pengaruhnya terhadap mortalitas $N$. viridula.

\section{METODE PENELITIAN}

Penelitian ini dilaksanakan di Laboratorium Hama Fakultas Pertanian Universitas Lampung sejak bulan Juli 2014 sampai dengan bulan Desember 2014.

Penelitian ini terdiri dari 2 tahap yang disusun dalam Rancangan Acak Lengkap (RAL). Tahap pertama yaitu pengujian kompatibilitas jamur entomopatogen $M$. anisopliae pada PDA setelah diberi ekstrak daun babadotan dilakukan dengan 4 perlakuan dan 4 ulangan. Tahap kedua adalah aplikasi campuran suspensi $M$. anisopliae dan ekstrak daun babadotan terhadap kepik hijau ( $N$. viridula) dilakukan dengan 6 perlakuan dan 4 ulangan.

Data yang diperoleh diuji dengan sidik ragam dan dilanjutkan dengan uji BNT dengan taraf nyata 5\%. Biakan murni jamur diperoleh dari UPTD Balai Perlintan Tegineneng, Lampung. Balai Pengembangan Proteksi Tanaman Tegineneng, Lampung. Jamur diperbanyak pada media Potato Dextrose Agar (PDA) dan media jagung yang diinkubasi selama \pm 2 minggu pada suhu ruang.

Ekstrak daun babadotan yang digunakan pada pengujian kompatibilitas dan pengujian aplikasi terhadap mortalitas kepik hijau sebanyak $1 \mathrm{ml}, 2 \mathrm{ml}, 3 \mathrm{ml}$. Pada masing- masing ekstrak babadotan ditambahkan suspensi $M$. anisopliae $10 \mathrm{ml}$ dan perata perekat (Agristick) sebanyak $1 \mathrm{ml} \mathrm{L}^{-1}$.

\section{Pengujian kompatibiitas}

Daya kecambah konidia M. anisopliae. Hasil pemanenan spora $M$. anisopliae pada PDA tanpa penambahan ekstrak daun babadotan sebagai kontrol dan pemanenan spora pada PDA yang telah dicampur dengan ekstrak daun babandotan sesuai dengan masingmasing perlakuan. Pemanenan dilakukan dengan menambahkan $5 \mathrm{ml}$ aquades pada PDA Kemudian dituangkan ke dalam tabung reaksi. Setelah itu, suspensi konidia $M$. anisopliae diinkubasikan pada suhu $25^{\circ} \mathrm{C}$ selama 24 jam. Perkecambahan konidia diamati menggunakan mikroskop cahaya. Konidia dinyatakan berkecambah apabila panjang tabung kecambah telah melebihi diameter konidia. Daya kecambah konidia menurut Alves et al. (1998) dalam Depieri et al. (2005) ditentukan dengan rumus:

$$
\mathrm{V}=\frac{\mathrm{K} 1}{\mathrm{~K} 2} \mathrm{X} 100 \%
$$

Keteragan:

$\mathrm{V}=$ daya kecambah konidia (\%),

$\mathrm{K} 1=$ jumlah konidia yang berkecambah,

$\mathrm{K} 2=$ jumlah konidia yang diamati.

Persentase penurunan daya kecambah konidia menurut Alves et al. (1998) dalam Depieri et al. (2005) dihitung dengan rumus:

$$
\mathrm{Mr}=\frac{\mathrm{M} 2-\mathrm{M} 2}{\mathrm{M} 1} \times 100 \%
$$

keterangan:

$\mathrm{Mr}=$ persentase penurunan daya kecambah,

M1= daya kecambah konidia pada media yang tidak diberi ekstrak daun babadotan (kontrol)

M2= daya kecambah konidia pada media yang diberi ekstrak daun babadotan

Pertumbuhan Koloni. Pengaruh ekstrak daun babadotan terhadap pertumbuhan koloni cendawan ditentukan dengan cara mengukur diameter koloni cendawan setiap lima hari yang dimulai dari hari ke-5 sampai hari ke-15 setelah inokulasi. Pertumbuhan koloni diukur pada setiap spot pertumbuhan koloni $M$. ansopliae pada masing-masing perlakuan. Persentase penurunan pertumbuhan koloni cendawan menurut Alves et al. (1998) dalam Depieri et al. (2005) dihitung dengan rumus:

$$
\mathrm{Nr}=\frac{\mathrm{N} 1}{\mathrm{~N} 2} \times 100 \%
$$

keterangan :

$\mathrm{Nr}=$ Persentase penurunan pertumbuhan koloni,

$\mathrm{N} 1=$ Pertumbuhan koloni cendawan pada media yang tidak diberi ekstrak daun babadotan,

N2= Pertumbuhan koloni cendawan pada media yang diberi ekstrak daun babadotan

Sporulasi. Pengaruh ekstrak babadotan terhadap sporulasi cendawan ditentukan dengan menghitung jumlah spora yang dihasilkan cendawan pada masingmasing perlakuan setelah diinkubasi selama 15 hari pada cawan petri. Konidia cendawan dipanen dengan cara menambahkan $5 \mathrm{ml}$ akuades steril dalam cawan Petri. Konidia dilepaskan dari media dengan menggunakan kuas halus. Suspensi disaring dan konsentrasi konidia dihitung dengan menggunakan hemositometer. Persentase penurunan sporulasi menurut Alves et al. (1998) dalam Depieri et al. (2005) dihitung dengan rumus :

$$
\mathrm{Sr}=\frac{\mathrm{S} 1-\mathrm{S} 2}{\mathrm{~S} 1} \times 100 \%
$$


keterangan :

$\mathrm{Sr}=$ persentase penurunan sporulasi,

$\mathrm{S} 1=$ jumlah konidia yang dihasilkan cendawan pada media yang tidak diberi ekstrak daun babadotan (kontrol),

$\mathrm{S} 2=$ jumlah konidia yang dihasilkan cendawan pada media yang diberi ekstrak daun babadotan

Perhitungan Nilai Kompatibilitas. Untuk mengetahui kompatibilitas ekstrak daun babadotan terhadap $M$. anisopliae, data hasil pengamatan kompatibilitas dimasukkan ke dalam rumus T dari Alves et al. (1998) dalam Depieri et al. (2005) sebagai berikut :

$$
\mathrm{T}=\frac{[20(\mathrm{VG})+80(\mathrm{SP})]}{100}
$$

keterangan:

$\mathrm{T}=$ nilai kompatibilitas,

$\mathrm{VG}=$ nilai relatif pertumbuhan koloni perlakuan dibandingkan dengan kontrol (\%),

$\mathrm{SP}=$ nilai relatif sporulasi perlakuan dibandingkan dengan kontrol (\%).

Nilai T dibagi kedalam kategori sebagai berikut: 0-30 sangat toksik; 31-45 toksik; 46-60 kurang toksik; dan $>60$ tidak toksik atau kompatibel.

Pengaruh aplikasi ekstrak jamur entomopatogen $M$. anisopliae dan pestisida nabati ekstrak daun babadotan (A. conyzoides) terhadap mortalitas $N$. viridula. Setiap satuan percobaan menggunakan serangga uji nimfa kepik hijau instar 4 atau 5 sebanyak 10 ekor. Aplikasi dilakukan 3 kali penyemprotan pada masing-masing perlakuan sebanyak $(2 \mathrm{ml})$ Indikasi kematian dilakukan dengan cara mengamati serangga yang mati di bawah mikroskop, apakah pada tubuh serangga uji tumbuh cendawan $M$. anisopliae.
Persentase kematian serangga dihitung dengan rumus sebagai berikut (Rustama et al., 2008):

$$
\mathrm{M}=\frac{\mathrm{n}}{\mathrm{N}} \times 100 \%
$$

keterangan:

$\mathrm{M}=$ mortalitas serangga $(\%)$

$\mathrm{n}=$ serangga yang mati (ekor)

$\mathrm{N}=$ jumlah serangga yang di uji

\section{HASIL DAN PEMBAHASAN}

\section{Pengujian kompatibilitas}

Daya kecambah konidia M. anisopliae. Hasil penelitian menunjukkan bahwa perlakuan penambahan ekstrak daun babadotan pada PDA sebagai media pertumbuhan $M$. anisopliae secara nyata berpengaruh terhadap daya kecambah konidia M. anisopliae. Daya kecambah konidia yang dipanen dari koloni $M$. anisopliae yang tumbuh pada media PDA dengan penambahan beberapa taraf konsentrasi dapat terlihat pada Tabel 1.

Pada tabel 1 menunjukkan bahwa pestisida nabati ekstrak babadotan yang ditambahkan pada media PDA secara nyata menurunkan daya kecambah konidia jamur M. anisopliae. Pada perlakuan X1 dengan penambahan $1 \mathrm{ml}$ ekstrak daun babadotan nyata menurunkan daya kecambah konidia sampai $45,42 \%$. Bahkan pada perlakuan X2 dan X3 dengan penambahan $2 \mathrm{ml}$ dan $3 \mathrm{ml}$ ekstrak daun babadotan daya kecambah konidia M.anisoplaie hanya $8,04 \%$ dan $6,11 \%$. Semakin tinggi penambahan ekstrak daun babadotan maka akan semakin tinggi tingkat penurunannya.

Penurunan daya kecambah dapat perpengaruh terhadap kemampuan $M$. anisopliae dalam membunuh serangga hama karena perkecambahan konidia merupakan tahap penting dalam proses menginfeksi serta

Tabel 1. Pengaruh pemberian ekstrak daun babadotan terhadap daya kecambah konidia $M$. anisopliae setelah inkubasi selama 24 jam

\begin{tabular}{ccc}
\hline $\begin{array}{c}\text { Perlakuan konsentrasi ekstrak } \\
\text { daun babadotan }\end{array}$ & Daya kecambah konidia $\%$ & Presentase penurunan \\
\hline X0 (Kontrol 0 ml/10 ml PDA & $40,96 \mathrm{a}$ & 0,00 \\
X1 $(1 \mathrm{ml} / 10 \mathrm{ml}$ PDA $)$ & $22,36 \mathrm{~b}$ & 45,42 \\
X2 $(2 \mathrm{ml} / 10 \mathrm{ml}$ PDA $)$ & $8,04 \mathrm{c}$ & 80,37 \\
X3 (3 ml/10 ml PDA $)$ & $6,11 \mathrm{~d}$ & 85,07 \\
\hline Pr $<$ F & 0,0001 & - \\
BNT 0,05 & 1,1936 & - \\
\hline
\end{tabular}

Keterangan: $\operatorname{Pr}<\mathrm{F} 0,1=$ sangat nyata. Nilai sekolom yang diikuti huruf yang sama berarti tidak berbeda nyata pada Uji BNT taraf nyata $5 \%$. 
membunuh serangga hama (Tanada \& Kaya 1993; Bidochka et al., 2000 dalam Trizelia \& Rusli, 2012).

Menurut Yohanes (2009) dalam Khairunnisa et al. (2014) jamur M. anisopliae memiliki daya kecambah spora diatas $80 \%$ yang memenuhi syarat untuk dikembangkan. Penggunaan jamur entomopatogen dalam pengendalian hama antara lain ditentukan oleh konsentrasi atau kepadatan dan daya kecambah spora

Pertumbuhan koloni. Hasil percobaan menunjukkan bahwa ekstrak daun babadotan yang ditambahkan pada media PDA menghambat pertumbuhan koloni jamur entomopatogen $M$. anisopliae. Pada perlakuan dengan penambahan ekstrak babadotan $2 \mathrm{ml}$ dan $3 \mathrm{ml}$ secara nyata menghambat pertumbuhan koloni $M$. anisopliae Tabel 2

Pada perlakuan Y2 dan Y3 dengan penambahan $2 \mathrm{ml}$ dan $3 \mathrm{ml}$ ekstrak babadotan menunjukkan bahwa pertumbuhan koloni $M$. anisopliae pada hari ke 15 hanya sebesar 2,17 dan $1,97 \mathrm{~cm}$, yang berarti mengalami penurunan pertumbuhan koloni jamur M. anisopliae antara 16,37-36,76\%. Penambahan ekstrak babadotan $2 \mathrm{ml}$ dan $3 \mathrm{ml}$ sudah bersifat toksik sehingga menghambat pertumbuhan koloni dan menurunkan persentase M. anisopliae. Terjadinya penurunan pertumbuhan koloni jamur entomopatogen pada media yang mengandung ekstrak tambahan dilaporkan oleh Nana et al. (2012), yang menyatakan bahwa penghambatan $M$. anisopliae juga terjadi saat dikombinasikan dengan the attraction aggregation and attachment pheromone (AAAP). AAAP pada konsentrasi $0,005 \% ; 0,01 \% ; 0,02 \%$ secara signifikan mengurangi diameter koloni $M$. anisopliae.

Sporulasi. Hasil penelitian menunjukkan bahwa perlakuan penambahan ekstrak daun babadotan pada PDA sebagai media pertumbuhan $M$. anisopliae secara nyata berpengaruh terhadap sporulasi $M$. anisopliae. Sporulasi yang dipanen dari koloni M. anisopliae yang tumbuh pada media PDA dengan penambahan beberapa taraf konsentrasi dapat terlihat pada Tabel 3.

Tabel 2. Pengaruh pemberian ekstrak daun babadotan terhadap pertumbuhan koloni $M$. anisopliae setelah inkubasi selama 15 hari

\begin{tabular}{ccc}
\hline $\begin{array}{c}\text { Perlakuan konsentrasi ekstrak daun } \\
\text { babadotan }\end{array}$ & Jumlah konidia $\left(\mathrm{x} 10^{8} / \mathrm{ml}\right)$ & Presentase penurunan (\%) \\
\hline V0 (Kontrol 0 ml/10 ml PDA) & $40,45 \mathrm{a}$ & 0 \\
V1 $(1 \mathrm{ml} / 10 \mathrm{ml}$ PDA $)$ & $20,35 \mathrm{~b}$ & 49,69 \\
V2 $(2 \mathrm{ml} / 10 \mathrm{ml}$ PDA $)$ & $10,15 \mathrm{c}$ & 74,90 \\
V3 $(3 \mathrm{ml} / 10 \mathrm{ml}$ PDA $)$ & $9,35 \mathrm{~d}$ & 76,88 \\
\hline Pr $<$ & 0,0001 & - \\
BNT 0,05 & 0,6559 & - \\
\hline
\end{tabular}

Keterangan: $\operatorname{Pr}<$ F 0,1 = sangat nyata. Nilai sekolom yang diikuti huruf yang sama berarti tidak berbeda nyata pada Uji BNT taraf nyata $5 \%$.

Tabel 3. Pengaruh pemberian ekstrak daun babadotan terhadap sporulasi M. anisopliae setelah inkubasi selama 15 hari

\begin{tabular}{|c|c|c|c|c|c|c|}
\hline \multirow{2}{*}{$\begin{array}{c}\text { Perlakuan konsentrasi ekstrak } \\
\text { daun babadotan }\end{array}$} & \multicolumn{6}{|c|}{ Diameter koloni $(\mathrm{cm})$} \\
\hline & 5 hsa & $\begin{array}{c}\% \\
\text { penurunan }\end{array}$ & 10 hsa & $\begin{array}{c}\% \\
\text { penurunan }\end{array}$ & 15 hsa & $\begin{array}{c}\% \\
\text { penurunan }\end{array}$ \\
\hline Y0 (Kontrol $0 \mathrm{ml} / 10 \mathrm{ml}$ PDA) & $1,12 \mathrm{a}$ & 0,00 & $1,81 \mathrm{a}$ & 0,00 & $3,11 \mathrm{a}$ & 0,00 \\
\hline $\mathrm{Y} 1(1 \mathrm{ml} / 10 \mathrm{ml}$ PDA $)$ & $0,91 \mathrm{~b}$ & 18,67 & $1,59 \mathrm{~b}$ & 12,12 & $2,60 \mathrm{~b}$ & 16,37 \\
\hline Y2 (2 ml/10 ml PDA) & $0,78 \mathrm{c}$ & 30,22 & $1,51 \mathrm{~b}$ & 16,80 & $2,17 \mathrm{c}$ & 30,34 \\
\hline $\mathrm{Y} 3(3 \mathrm{ml} / 10 \mathrm{ml} \mathrm{PDA})$ & $0,78 \mathrm{c}$ & 30,67 & $1,42 \mathrm{~b}$ & 21,76 & $1,97 \mathrm{c}$ & 36,76 \\
\hline $\operatorname{Pr}<\mathrm{F}$ & 0,0002 & - & 0,0025 & - & 0,0001 & - \\
\hline BNT 0,05 & 0,1271 & - & 0,1771 & - & 0,2724 & - \\
\hline
\end{tabular}

Keterangan: $\operatorname{Pr}<$ F $0,1=$ sangat nyata. Nilai sekolom yang diikuti huruf yang sama berarti tidak berbeda nyata pada Uji BNT taraf nyata $5 \%$. 
Tabel 3 menunjukkan bahwa pada perlakuan V1 penambahan $1 \mathrm{ml}$ ekstrak daun babadotan secara nyata menghambat $M$. anisopliae bersporulasi dengan penurunan sampai 49,69\%. Bahkan pada perlakuan V3 penambahan $3 \mathrm{ml}$ ekstrak daun babadotan, $M$. anisopliae bersporulasi hanya mencapai $9,35 \%$ dan presentase penurunan bersporulasimencapai $76,88 \%$. Pada perlakuan dengan penambahan ekstrak babadotan.Persentase penurunan sangat bervariasi tergantung pada jumlah ekstrak babadotan yang diberikan.

Penurunan sporulasi $M$. anisopliae juga dilaporkan oleh Hirose et al. (2001) menyatakan bahwa penambahan EM-4, supermagro, dan minyak nimbi menyebabkan penurunan sporulasi sekitar 50\% (49, $65 \%, 56,94 \%$ dan 54,35\%), sedangkan kemampuan sporulasi digunakan sebagai kemampuan isolat untuk penetrasi ke inang sasaran. Semakin tinggi tingkat sporulasi berarti semakin besar kemampuan jamur entomopatogen menginfeksi (Trizelia, 2005 dalam Mardiana et al., 2015).

Nilai Kompatibilitas. Berdasarkan nilai T, klasifikasi kompatibilitas ekstrak daun babadotan dengan jamur entomopatogen M. anisopliae dapat dilihat pada Tabel 4.

Perlakuan dengan ekstrak daun babadotan pada perlakuan $1 \mathrm{ml}$ menunjukkan nilai pada peringkat kurang toksik terhadap jamur $M$. anisopliae dan apabila ditingkatkan jumlah penambahan ekstrak daun babadotan hingga $3 \mathrm{ml}$ bersifat toksik yang artinya tidak kompatibel terhadap jamur $M$. anisopliae. Nilai kompatibilitas ini menunjukkan bahwa ekstrak daun babadotan dan $M$. anisopliae tidak kompatibel dan didukung oleh data penurunan daya kecambah konidia, pertumbuhan koloni dan sporulasi jamur M. anisopliae secara nyata. Oleh karena itu penggunaan ekstrak babadotan yang tidak kompatibel dengan jamur entomopatogen M.anisopliae tidak disarankan untuk diaplikasikan secara bersamaan.

Trizelia (2008) dalam Mardiana et al. (2015) melaporkan bahwa jamur entomopatogen $M$. anisopliae yang dikombinasikan dengan ekstrak etanol daun dan bunga paitan tidak kompatibel. Pada tiga konsentrasi $(0,1 ; 0,3 ; 0,5 \%)$ secara nyata mengurangi pertumbuhan koloni, daya kecambah, dan sporulasi $M$. anisopliae.

Hirose et al. (2001) juga menyatakan bahwa jamur entomopatogen $M$. anisopliae yang dikombinasikan dengan EM-4, supermagro dan minyak nimbi secara nyata tidak kompatibel bila diaplikasikan secara bersamaan. Hal ini dikarenakan penambahan EM-4, supermagro dan minyak nimbi menurunkan daya kecambah, pertumbuhan koloni serta sporulasi $M$. anisopliae mencapai $50 \%$.

Mortalitas $N$. viridula setelah aplikasi suspensi
jamur entomopatogen $M$. anisopliae dan pestisida
nabati ekstrak daun babadotan. Hasil percobaan menunjukkan bahwa ekstrak daun babadotan dan suspensi $M$. anisopliae berpengaruh nyata terhadap mortalitas $N$. viridula Tabel 5.

Tabel 5 menunjukkan bahwa aplikasi tunggal suspensi $M$. anisopliae $(\mathrm{H} 2)$ menyebabkan mortalitas N. viridula sebesar $63,33 \%$. Aplikasi tunggal pestisida nabati ekstrak daun babadotan (H3) menyebabkan mortalitas $N$. viridula sebesar $70,00 \%$, dimana nilai tersebut tidak berbeda nyata dengan perlakuan $\mathrm{H} 2$.

Mortalitas $N$. viridula pada perlakuan aplikasi suspensi M. anisopliae $10 \mathrm{ml}$ ditambahkan ekstrak daun babadotan $1 \mathrm{ml}(\mathrm{H} 4)$ sebesar 70,00\% dan tidak berbeda nyata dengan mortalitas $N$. viridula pada perlakuan $\mathrm{H} 2$ dan H3. Namun perlakuan aplikasi suspensi $M$. anisopliae $10 \mathrm{ml}$ ditambahkan ekstrak daun babadotan $2 \mathrm{ml}$ (H5) dan aplikasi suspensi M. anisopliae $10 \mathrm{ml}$ ditambahkan ekstrak daun babadotan $3 \mathrm{ml}$ (H6) menyebabkan mortalitas $N$. viridula yang lebih tinggi dan secara nyata berbeda dengan mortalitas pada perlakuan $\mathrm{H} 2$.

Aplikasi tunggal suspensi $M$. anisopliae atau ekstrak daun babadotan cukup efektif dapat menyebabkan mortalitas $N$. viridula. Pada penambahan $1 \mathrm{ml}$ ekstrak babadotan pada $10 \mathrm{ml}$ suspensi $M$. anisopliae tidak secara nyata meningkatkan mortalitas $N$. viridula. Namun penambahan ekstrak daun babadotan $2 \mathrm{ml}$ dan $3 \mathrm{ml}$ dapat meningkatkan mortalitas $N$. viridula.

Tabel 4. Klasifikasi kompatibilitas ekstrak babadotan dengan jamur entomopatogen M. anisopliae

\begin{tabular}{ccc}
\hline Perlakuan & $\mathrm{T}$ & Tingkat kompatibilitas* \\
\hline $1 \mathrm{ml}$ & 57,10 & Kurang toksik \\
$2 \mathrm{ml}$ & 34,91 & Toksik \\
$3 \mathrm{ml}$ & 32,54 & Toksik \\
\hline
\end{tabular}

* klasifikasi menurut Alves et al. (1998) dalam Depieri et al. (2005) 
Tabel 5. Mortalitas N.viridula 7 hari setelah aplikasi

\begin{tabular}{|c|c|}
\hline Perlakuan & Mortalitas N. viridula L. \% \\
\hline H1 (Kontrol) & $0,00 \mathrm{c}$ \\
\hline $\begin{array}{l}\mathrm{H} 2 \text { (Suspensi M. anisopliae } 10^{7} \text { konidia } \\
\text { spora/ } \mathrm{ml} \text { ) }\end{array}$ & $63,33 \mathrm{~b}$ \\
\hline H3 (Ekstrak daun babadotan) & $70,00 \mathrm{ab}$ \\
\hline $\begin{array}{l}\text { H4 (Suspensi M. anisopliae } 10 \mathrm{ml} \text { ditambahkan } \\
\text { ekstrak daun babadotan } 1 \mathrm{ml} \text { ) }\end{array}$ & $70,00 \mathrm{ab}$ \\
\hline $\begin{array}{l}\text { H5 (Suspensi M. anisopliae } 10 \mathrm{ml} \text { ditambahkan } \\
\text { ekstrak daun babadotan } 2 \mathrm{ml} \text { ) }\end{array}$ & 76,66 a \\
\hline $\begin{array}{l}\text { H6 (Suspensi M. anisopliae } 10 \mathrm{ml} \text { ditambahkan } \\
\text { ekstrak daun babadotan } 3 \mathrm{ml} \text { ) }\end{array}$ & 76,66 a \\
\hline $\operatorname{Pr}<F$ & 0,0001 \\
\hline BNT 0,05 & 10,271 \\
\hline
\end{tabular}

Keterangan: $\operatorname{Pr}<\mathrm{F} 0,1$ = sangat nyata. Nilai sekolom yang diikuti huruf yang sama berarti tidak berbeda nyata pada Uji BNT taraf nyata $5 \%$.

Data ini menunjukkan bahwa aplikasi secara terpisah jamur entomopatogen $M$. anisopliae dan ekstrak babadotan lebih efektif dan hemat dibandingkan penggunaan secara bersama. Hal ini berarti ekstrak babadotan dan jamur entomopatogen $M$. anisopliae tidak kompatibel. Keduanya tidak efektif jika diaplikasikan secara bersamaan untuk mengendalikan hama kepik hijau (N. viridula).

\section{KESIMPULAN}

Cendawan entomopatogen $M$. anisopliae dengan pestisida nabati ekstrak babadotan tidak kompatibel. Hasil uji menunjukkan bahwa ekstrak babadotan menghambat pertumbuhan koloni, daya kecambah konidia dan sporulasi.Tingkat penghambatan bervariasi bergantung pada jumlah penambahan ekstrak babadotan. 2. Aplikasi suspensi M. ansiopliae dan aplikasi ekstrak daun babadotan secara tunggal menyebabkan mortalitas $N$. viridula yang tidak berbeda nyata antara keduanya. Aplikasi suspensi $M$. anisopliae dengan penambahan ekstrak daun babadotan $2 \mathrm{ml}$ dan $3 \mathrm{ml}$ menyebabkan mortalitas yang lebih tinggi dibandingkan mortalitas $N$. viridula pada aplikasi tanpa penambahan ekstrak babadotan.

\section{DAFTAR PUSTAKA}

Depieri R.A., S.S. Martinez., \& Jr.A.O.Menezes.2005. Compatibility Of The Fungus Beauveria bassiana (Bals.) Vuill. (Deuteromycetes) with of Neem Seeds and Leaves and The Emulsible Oil. Neotropical Ent. 34(4): 601-606
Harahap, I. S. dan B. Tjahjono, B. 2004.Pengendalian Hama Penyakit Padi. Penebar Swadaya. Jakarta.114 hlm.

Hirose, E., P.M.O.J. Neves., J.A.C. Zequi., L.H. Martins., C.H. Peralta \& A. Moino Jr. 2001. Effect of biofertilizers and neem oil on the entomopathogenic fungi Beauveria bassiana (Bals.) Vuill. And Metarhizium anisopliae (Metsch.) Sorok. Braz. Arch. Biol. Techn. 44: 409-423.

Kalshoven. 1981. The Pests of Crops in Indonesia. Revised and translated by P.A. Van der Laan. P.T. Ichtiar Baru Van Hoeve. Jakarta.701 hlm.

Khairunnisa.,A. Martina. \&Titrawani. 2014. Uji Efektivitas Jamur Metarhizium anisopliae Cps.T.A Isolat Lokal terhadap Hama Rayap (Coptotermes curvignathus). JOM MIPA Universitas Riau. 1(2): 430-438.

Mardiana, Y., D. Salbiah.,L.J. Hennie. 2015. Penggunaan Beberapa Konsentrasi Beauveria bassiana Vuillemin Lokal untukMengendalikan Maruca testulalis Geyer pada Tanaman Kacang Panjang (Vigna sinensis L.). JOM Faperta Universitas Riau. 2(1): 1-11.

Nana P., N.K. Mania M., R.O. araga., H.I. Boga., H.L. Kutima and J.N. Eloff. 2012 Compatibility between Calpurnia aurea leaf extract, attraction aggregation and attachment pheromone, and entomopathogenic fungus Metarhizium anisopliae on viability, growth, and virulence of the pathogen. Journal of Pest Science. 85:109115 
Prayogo, Y. 2011. Sinergisme Cendawan Entomopatogen Lecanicillium lecanii dengan Insektisida Nabati untuk Meningkatkan Efikasi Pengendalian Telur Kepik Coklat Riptortus linearis pada Kedelai. Jurnal Hama dan Penyakit Tumbuhan Tropika 11 (2): 166-178.

Rustama, M., M. Melanie \& B. Irawan. 2008. Patogenisitas Jamur Entomopatogen Metarhizium anisopliae terhadap Crocidolomia pavonana Fab. dalam Kegiatan Studi Pengendalian Hama Terpadu Tanaman Kubis dengan Menggunakan Agensia Hayati. (Laporan Akhir Penelitian Peneliti Muda). Universitas Padjajaran. $58 \mathrm{hlm}$

Samsudin. 2008. Virus Patogen Serangga Bioinsektisida Ramah Lingkungan. Diakses Desember 2014 dari http://Lembagapertanian sehat/ develop Useful innovation for farmers Rubrik.

Samuels, R.I. 1998. Systematics Morphology and Physiology: A Sensitive bioassay for Dextruxins, Cyciodepsipeptides from The Culture Filtrates of The Entomopathonic Fungus Metarhizium anisopliae (Metch.) Sorok.An Soc. Entomol. 27(2): 229-235
Sarjan, M. 2007. Potensi Pemanfaatan Insektisida Nabati dalam Pengendalian Hama pada Budidaya Sayuran Organik. Universitas Mataram. Lombok. 7 hlm.

Sianturi, E.S. 2009.Uji Efektivitas beberapa Insektisida Nabati pada Tanaman Kacang Panjang terhadap Hama Maruca testutalis. Universitas Sumatera Utara. Medan. 183 hlm.

Trizelia dan R. Rusli. 2012. Kompatibilitas Cendawan Entomopatogen Beauveriabassiana (bals) Vuill (Deuteromycotina: Hyphomycetes) dengan Minyak Serai Wangi. J. HPT Tropika. 12(1): 78 -84 ,

Willis, M. 2010. Formulasi Pestisida Nabati Berbahan Aktif Eugenol, Sitronela, Sinamoldehid, Curcumin dan Xanthorizol yang Efektif Menekan Conopomorpha cramerella dan Helopeltis sp. pada Kakao (40-50\%) dan Tidak Membunuh Musuh Alami. Balitro, Bogor. 31 hlm 